\title{
Transmigration program can be failed, but transmigrant stay life: Portraits of Transmigrant Families in Sorong Regency, West Papua
}

\section{Program transmigrasi boleh gagal, tetapi transmigran tetap bertahan hidup: Potret Keluarga Transmigran di Kabupaten Sorong, Papua Barat}

\author{
Irin Oktafiani ${ }^{1}$, Herry Yogaswara ${ }^{2}$ \\ ${ }^{1}$ Research Center for Population, Indonesian Institute of Sciences. Email: irin.oktafiani@gmail.com \\ 2 Research Center for Population, Indonesian Institute of Sciences. Email: yogaswaralipi@yahoo.com
}

\begin{tabular}{|c|c|}
\hline ARTICLE INFO & ABSTRACT \\
\hline $\begin{array}{l}\text { Keywords: } \\
\text { West Papua; } \\
\text { Transmigration; } \\
\text { Adaptation; ethnography. } \\
\text { How to cite: } \\
\text { Oktafiani, I., Yogaswara, } \\
\text { H. (2020). Transmigration } \\
\text { program can be failed, but } \\
\text { transmigrant stay life: } \\
\text { Portraits of Transmigrant } \\
\text { Families in Sorong } \\
\text { Regency, West Papua. } \\
\text { ETNOSIA: Jurnal } \\
\text { Etnografi Indonesia. 5(2): } \\
\text { 200 - 220. }\end{array}$ & $\begin{array}{l}\text { Transmigration has been applied in Indonesia as a development and } \\
\text { population distribution strategy. Historically, the Indonesian } \\
\text { transmigration program has a long story since the Ethical Policy unti } \\
\text { now. Furthermore, transmigration had been claimed and became the } \\
\text { primary strategy of development in the New Order. Despite all the } \\
\text { hope about transmigration, people considered this program failed } \\
\text { nationally because its top-down system has caused a new problem in } \\
\text { the destination area. However, some transmigrants have been } \\
\text { succeeded and struggled in the new area. This paper described the } \\
\text { bright side of what-so-called failed transmigration in Segun, Sorong, } \\
\text { West Papua. Data are collected by multi-sited ethnography with } \\
\text { observation and in-depth interviews of two successful Javanese } \\
\text { families in Segun. In conclusion, this paper argues that although the } \\
\text { program has failed nationally, each transmigrant had its strategy to } \\
\text { survive and succeed in the new area. }\end{array}$ \\
\hline $\begin{array}{l}\text { DOI: } \\
\text { 10.31947/etnosia.v5i2.10723 }\end{array}$ & \\
\hline
\end{tabular}

\section{Pendahuluan}

Migrasi atau perpindahan penduduk memiliki pola dan faktor penentu. Pola dan faktor ini ditentukan oleh beberapa aspek yaitu, kemiskinan, ketidaksetaraan, peran pemerintah, peran relasi, dan perbedaan gender dalam intensi bermigrasi (Black, Richard; Biao, Xiang; Collyer, Michael; Heering, Godfried Liesbeth Engbersen; Markova, 2006, pp. 45-55). Keberhasilan migrasi pada akhirnya juga berhubungan dengan 
bagaimana aspek ini terwujud dalam masyarakat. Ditambah lagi, migrasi dianggap sebagai produk dari kemiskinan (p.41). Kemiskinan dan ketidaksetaraan memaksa individu atau masyarakat untuk berpindah dari daerah asal ke tempat yang menyediakan lapangan kerja. Oleh karena itu migrasi seringkali dilakukan secara sukarela (voluntary) demi kehidupan yang lebih baik. Migrasi juga sangat tergantung konteks dan lokus dari daerah penerima, khususnya aspek politik, ekonomi dan sosial budaya, serta konteks kesejarahannya. Khususnya ketika konteks migrasi ini terjadi di wilayah Tanah Papua, maka persoalan kesejarahan, dinamika politik, tingkat ekonomi serta keragaman budaya antara penduduk asli dan pendatang mempunyai dinamika sendiri.

Tulisan ini tentang dua proses migrasi yang terjadi secara beriringan, yaitu rekayasa demografis (demographic engineering) melalui program transmigrasi dan migrasi spontan yang dilakukan oleh sebuah keluarga transmigrasi etnis Jawa dalam Tanah Papua, khususnya di wilayah Kabupaten Sorong, (kini) Provinsi Papua Barat. Aspek temporalnya adalah situasi pada masa 'orde baru', sekitar tahun 1992, hingga akhir tahun 2020. Pada situasi temporal yang berbeda, terdapat dinamika relasi antar etnis, diantaranya munculnya konsep 'Orang Asli Papua' (OAP) melalui Undang-undang Otonomi Khusus pada tahun 2001 yang mempunyai dampak klaim terhadap sumbersumber agraria maupun hubungan antar etnis lainnya.

Transmigrasi di Papua telah dimulai sejak tahun 1962. Laporan kantor wilayah Transmigrasi Papua (1997) menunjukan secara makro peningkatan ekonomi di lokasi penempatan transmigrasi dapat dikatakan berhasil. Namun, secara mikro upaya peningkatan kesejahteraan transmigrasi lokal dikatakan kurang dan/tidak berhasil. Sinulingga (Apomfires, 2000) melaporkan di beberapa lokasi transmigrasi di Papua tidak mengalami perkembangan sebagaimana harapan pemerintah, diantaranya transmigran meninggalkan lokasi permukiman dan mencari pekerjaan di luar sektor transmigrasi yang digariskan pemerintah; penyediaan sarana dan prasarana untuk pemasaran hasil produksi tani terbatas atau masih kurang; transmigran menjual lahan garapannya kepada orang lain dan kemudian pulang ke daerah asalnya (p.425). Mulai tahun 1980-an orang Papua menolak transmigrasi, penolakan bukan hanya dari kalangan masyarakat, akan tetapi semua Bappeda Tingkat II, meniadakan transmigrasi dianggap sebagai pencegahan konflik paling ampuh (p.428).

Pemerintah Indonesia menyatakan transmigrasi sebagai salah satu instrumen kebijakan pendistribusian penduduk (Tirtosudarmo, 2013, p. 1). Sebagai salah satu instrumen kebijakan pemerintah, transmigrasi dianggap dapat membantu peningkatan kesejahteraan masyarakat. Transmigrasi juga merupakan jalan integrasi penduduk yang dibutuhkan untuk mendukung pembangunan nasional. Sejarah mencatat bahwa transmigrasi di Indonesia sudah dimulai dari masa pendudukan Belanda di Indonesia, tepatnya terjadi dalam masa Politik Etis di Indonesia tahun 1905 (Kementerian Desa Pembangunan Daerah Tertinggal dan Transmigrasi RI, 2015; Tirtosudarmo, 2013). Dicetuskannya transmigrasi di Indonesia diawali dengan kekhawatiran Pemerintah Kolonial Belanda yang melihat kepadatan penduduk di Pulau Jawa yang tinggi. Kepadatan penduduk ini dinilai tidak bisa diabaikan begitu saja karena akan berakibat buruk bagi keseimbangan pemerintahan karena sarana hidup layak tidak mencukupi. 
Setelah masa pendudukan Belanda, transmigrasi masih dilanjutkan sampai era reformasi (2000-2009). Sayangnya, sebagai sebuah kebijakan nasional, program transmigrasi dianggap gagal (Arndt, 1983, p. 61). Kegagalan transmigrasi dikarenakan sifat program yang top-down seringkali mengabaikan kondisi daerah penempatan, baik dari aspek sosial, ekonomi, geografis, dan budaya. Kisah-kisah kegagalan transmigrasi diwarnai dengan banyaknya penggunaan dana transmigrasi yang tidak tepat pada individu maupun, gagal secara sosial budaya karena malah menimbulkan konflik di tempat baru, diantara pendatang dan penduduk lokal.

Sekalipun transmigrasi menyisakan kenangan mengenai kegagalan di daerah transmigrasi, tetapi program tersebut masih dianggap relevan sebagai alat pembangunan di masa depan (Harmadi \& Antarwati, 2014, p. 2). Dalam tulisan ini, bahkan, dapat dilihat bagaimana program transmigrasi dapat menjadi jalan pembuka kesuksesan sebuah keluarga. Bertahan, beradaptasi, kemudian mencintai tanah transmigrasi menjadi rangkaian hidup keluarga Karmidi dari Salatiga dan Joko dari Nganjuk. Bagian pertama tulisan ini akan menceritakan kronologi transmigrasi dan pandangan nasional mengenai transmigrasi di Indonesia. Transmigrasi dilihat sebagai jalan rekayasa sosial di Indonesia sekaligus sebagai upaya persebaran penduduk. Bagian kedua adalah penjelasan mengenai lokasi Segun sebagai wilayah transmigrasi SP (satuan pemukiman) di Kabupaten Sorong. Kemudian bagian ketiga berisi mengenai etnografi keluarga Karmidi yang berasal dari Salatiga yang berjuang menjadi transmigran di Segun dan Joko dari Nganjuk hingga bagaimana akhirnya keluarga ini dapat bertahan di wilayah tersebut. Pada bagian akhir, tulisan ini akan mencoba menganalisis kasus kesuksesan transmigrasi menggunakan aspek-aspek migrasi Richard Black, (Black, Richard; Biao, Xiang; Collyer, Michael; Heering, Godfried Liesbeth Engbersen; Markova, 2006) dan bagaimana strategi adaptasi dalam keterbatasan yang ditempuh oleh transmigran dan bagaimana migrasi sosial dapat terwujud sebagai pembelajaran dari peraturan transmigrasi pemerintah.

Tujuan penulisan artikel ini ada tiga. Pertama, pada tataran yang makro ingin memahami program transmigrasi sebagai sebuah program nasional. Kedua, memahami kondisi program transmigrasi di tanah Papua yang mempunyai dinamika politik dan relasi antar etnis yang bersifat khas, Ketiga, memahami potret program transmigrasi dan dinamika relasi antar etnis ini potret sebuah keluarga transmigran dalam konteks ruang dan waktu yang berbeda-beda.

Secara spesifik, tulisan ini akan mendeskripsikan bagaimana situasi dan kondisi transmigrasi pada masa Orde Baru dari sudut pandang transmigran Jawa yang berasal dari Salatiga dan Nganjuk. Dua keluarga yang memutuskan untuk berpindah dikarenakan nasib yang tidak menguntungkan di tanah kelahirannya. Lokasi transmigrasi dalam tulisan ini adalah Segun, Papua. Keluarga transmigran harus beradaptasi menghadapi dua kondisi yang kontras antara tanah Jawa dan tanah Papua, khususnya bagaimana sebuah keluarga transmigran mampu mengatasi permasalahan kultural, jejaring sosial, dan menghadapi lingkungan ekologis, khususnya ketika program dan tanah yang dijanjikan tidak sesuai dengan harapan pada awalnya. 
Tulisan ini memang memberikan fokus pada dua keluarga untuk memperlihatkan kesejarahan serta relasi-relasi yang dibangun oleh keluarga itu ketika masih di daerah asalnya, perjalanan menuju lokasi transmigrasi, dan upaya bertahan di lokasi asal transmigrasi, berpindah ke tempat lain demi mempertahankan hidup. Tentu saja ketika secara sengaja memilih dua keluarga ini, terdapat keluarga-keluarga transmigrasi lainnya di Sorong dari beragam profesi. Pilihan pada keluarga Karmidi (nama samaran) dan Pak Joko (nama samaran) dilakukan secara purposive untuk menampilkan potret yang lengkap tentang keseharian keluarga petani dan non-petani.

\section{Metode}

Tulisan ini merupakan bagian dari proses perjalanan kedua penulis dari kegiatan penelitian yang dilakukan oleh Lembaga Ilmu Pengetahuan Indonesian (LIPI) di Papua Barat ${ }^{1}$, khususnya di wilayah Sorong, baik Kota maupun Kabupaten Sorong. Pendekatan kualitatif dengan metode etnografi digunakan dalam tulisan ini. Sebelum fokus pada satu keluarga transmigran yang akhirnya menjadi inti dalam tulisan ini, kami memiliki relasi dengan beberapa migran lainnya di wilayah Sorong, termasuk migran spontan maupun transmigran. Teknik pemilihan informan kunci menggunakan cara snowballing. Pemilihan informan dilakukan dengan terlebih dahulu mendapatkan informan pangkal untuk mendapatkan gambaran awal tentang lokus wilayah penelitian, kemudian kami memilih informan kunci (key informant) yang dianggap dapat memberikan gambaran tentang pola kehidupan transmigran. Pemilihan dua keluarga dalam tulisan ini karena pertimbangan metodologis dari sisi permasalahan kependudukan, yaitu fenomena migrasi spontan dan sebagai transmigran yang mempunyai dua dimensi yang berbeda dari sisi motivasi sebuah keluarga ketika hendak melakukan mobilitas.

Pertemuan tidak sengaja dengan keluarga Pak Karmidi terjadi - tetapi menjadi titik balik penting memahami kisah transmigran -- karena menantunya seorang lelaki Bugis menjadi sopir yang kami tumpangi. Lelaki Bugis ini bercerita tentang pengalaman personalnya dari mulai anak-anak hingga dewasa berpindah dari satu kabupaten ke kabupaten lain di Kalimantan Timur hingga ke tanah Papua. Cerita menjadi lebih menarik, ketika dia menceritakan mertuanya adalah seorang transmigran dari Jawa. Pada satu waktu yang sama kami bertemu antara orang yang dikategorikan sebagai spontaneous migrant dan keluarga yang mewakili sebuah fenomena rekayasa demografis, bahkan memperlihatkan sebuah dinamika relasi sosial di Tanah Papua.

Di sisi lain, perjumpaan dengan keluarga Pak Joko terjadi ketika tim peneliti LIPI, sedang melacak perkembangan pendidikan di kabupaten Tambrauw dan menemukan peran penting pak Joko yang pernah menjadi guru senior di beberapa kabupaten di Papua Barat, sebelum berdinas di Dinas Pendidikan Tambrauw. Pak Joko adalah anak

${ }^{1}$ Herry Yogaswara pada tahun 2017 dan 2018 terlibat dalam kegiatan persiapan Ekspedisi Nusa Menggala (ENM), yaitu suatu ekspedisi dengan menggunakan kapal riset Baruna Jaya VIII di pulau-pulau kecil terluar provinsi Papua dan Papua Barat, serta tahun 2019 menjadi penanggung jawab kegiatan Prioritas Nasioanl (PN) Papua Kedeputian bidang Ilmu Pengetahuan Sosial dan Kemanusiaan (IPSK LIPI) di Papua Barat. Irin Oktafiani tahun 2018 menjadi anggota tim ENM di wilayah Tambrauw Provinsi Papua Barat dan Kabupaten SARMI di Provinsi Papua. Pada bulan Desember 2019, keduanya melakukan revisited di Sorong Papua Barat pada bulan Desember 2019. 
petani transmigran dari Jawa, tetapi kemudian berprofesi sebagai tenaga pendidik. Sementara sampai sekarang Pak Karmidi masih melanjutkan kehidupannya sebagai petani.

Pertemuan dan perbincangan yang intensif dengan keluarga Pak Karmidi berlangsung dua kali dalam suasana yang berbeda. Perjumpaan pertama terjadi pada bulan Agustus 2019 dan kedua kali bulan Desember 2019. Perjumpaan pada bulan Agustus 2019 berada dalam suasana mencekam, karena sedang terjadi berbagai aksi unjuk-rasa yang berakibat pada pembakaran unit usaah di Kota Sorong sebagai imbas dari permasalahan ujaran rasisme di kota Surabaya. Kejadian di Kota Sorong relatif mengejutkan, karena Provinsi Papua Barat, khususnya kota Kota Sorong mempunyai komposisi jumlah penduduk Orang Asli Papua (OAP) dan non-OAP yang seimbang, bahkan Kabupaten Sorong merupakan wilayah transmigrasi sejak tahun 1972. Suasana pasca kerusuhan, menjadikan perbincangan tentang relasi Pak Karmidi dengan tetangga dari etnis OAP menjadi satu bagian penting. Sedangkan perjumpaan kedua pada akhir bulan Desember 2019, dimana situasi kerusuhan sudah tidak terasa, sehingga perbincangan lebih banyak tentang proses-proses awal menjadi transmigran dan bagaimana proses kapitalisasi modal sosial dilakukan oleh Pak Karmidi agar bertahan hidup dan mendapatkan kesejahteraan yang lebih baik.

Selain pengumpulan data dengan wawancara, pengamatan dilakukan untuk melihat pola tempat tinggal dari keluarga Karmidi, khususnya bagaimana hubungan antar tetangga dari keluarga tersebut, termasuk hubungan dengan migran-migran yang ada di sekitar rumahnya, maupun tetangga dari etnis Orang Asli Papua (OAP). Kemudian untuk melihat konteks yang lebih luas, pendalaman kepustakaan mengenai transmigrasi di tanah Papua dan program transmigrasi secara nasional telah kami lakukan.

\section{Hasil penelitian dan pembahasan}

\section{- Sejarah Transmigrasi di Indonesia}

Transmigrasi di Indonesia dimulai dari awal abad 20 pada masa pendudukan Kerajaan Belanda yaitu Politik Etis yang digagas oleh C. Th van Deventer (Kementerian Desa Pembangunan Daerah Tertinggal dan Transmigrasi RI, 2015, p. 4; Ricklefs, 2008, pp. 189190; Tirtosudarmo, 2013, p. 6). Politik etis tercetus sebagai suatu usaha dari kerajaan Belanda untuk mensejahterakan penduduk Pulau Jawa sebagai akibat dari kekejaman tanam paksa. Terdapat tiga pokok prinsip dari Politi Etis, yaitu edukasi, irigasi, dan emigrasi. Emigrasi dianggap menjadi hal yang penting karena jumlah penduduk di Pulau Jawa sudah semakin banyak sehingga tidak semua penduduk bisa mendapatkan pendidikan dan lahan untuk dikerjakan secara layak. Dimulai dari sini, pemindahan penduduk keluar Pulau Jawa dilakukan, penduduk dipindahkan dari Jawa ke Lampung dan Sumatera Timur (Ricklefs, 2008, p. 194).

Selepas masa pendudukan Belanda di Indonesia (1945-1965) program transmigrasi masih dijalankan untuk mendukung pembangunan. Mohammad Hatta berpendapat bahwa transmigrasi perlu dijalankan dalam bentuk yang baru, yaitu pemindahan harus 
berjalan simultan dengan pembentukan lokasi industri di daerah tujuan (Tirtosudarmo, 2013, p. 14). Disamping ide pembentukan wilayah industri yang harus sejalan dengan transmigrasi, proses transmigrasi yang terwujud pada masa tersebut didukung oleh kondisi politik yang tidak stabil, yaitu adanya gerakan-gerakan separatis di daerah. Pemindahan penduduk dianggap sebagai jalan yang tepat, selain untuk mengurangi populasi penduduk di Pulau Jawa, tetapi juga sebagai upaya menyiapkan tenaga kerja dan mendukung strategi militer di daerah, serta mempercepat proses asimilasi (Hardjosudarmo 1965 dalam Tirtosudarmo, 2013, p. 18)). Lebih lanjut, bagi Adhiati dan Bobsien (Adhiati, M.Adriana Sri; Bobsien, 2001) tujuan utama pelaksanaan transmigrasi selain untuk mendukung pembangunan dan pendistribusian penduduk adalah untuk memanfaatkan secara efektif potensi dari pulau-pulau luar (tujuan transmigrasi).

Memasuki masa pemerintahan Orde Baru, tercatat, terdapat 18 periode transmigrasi dalam 6 rentang Pelita I - VI (Kementerian Desa Pembangunan Daerah Tertinggal dan Transmigrasi RI, 2015, pp. 4-6). Transmigrasi di masa Orde Baru pertama kali dikerjakan di bawah Departemen Transmigrasi dan Koperasi yang kemudian sampai kepada Pelita VI berubah nama menjadi Departemen Transmigrasi dan Pemukiman Perambah Hutan (PPH). Pada masa Orde Baru, program transmigrasi yang terkenal adalah Program Sitiung dengan transmigrasi bedol desa ${ }^{2}$. Dimulai dari periode Pelita 2 daerah tujuan transmigrasi sudah didirikan pemukiman untuk transmigran dan mulai berfokus pada pola usaha lain selain tanaman pangan, yaitu hutan tanaman industri (HTI), perkebunan inti rakyat (PIR), jasa industri, perikanan dan peternakan. Pada masa Pelita VI program transmigrasi yang terkenal adalah transmigrasi swakarsa mandiri (TSM). Pada masa ini transmigrasi sudah tidak sepenuhnya berpusat pada dana bantuan pemerintah. TSM merupakan inisiatif dari transmigran sendiri tetapi daerah tujuannya perpindahannya masih sama yaitu di luar Pulau Jawa.

Pada tabel 1, akan memperlihatkan dinamika pengelolaan transmigrasi di Indonesia berdasarkan periodesasi pembangunan lima tahun (Pelita) tahun 1969-1999, termasuk pegantian nomenklatur departemen/kementarian serta model programnya.

Tabel 1. Perkembangan Model Transmigrasi 1969-1999

\begin{tabular}{|c|c|c|c|}
\hline $\begin{array}{l}\text { Periode } \\
\text { Pelita }\end{array}$ & $\begin{array}{l}\text { Periode } \\
\text { Tahun }\end{array}$ & $\begin{array}{c}\text { Departemen/ } \\
\text { Kementerian Terkait }\end{array}$ & Model Program \\
\hline Pelita I & $\begin{array}{l}1969 / 1970- \\
1973 / 1974\end{array}$ & $\begin{array}{c}\text { Departemen Transmigrasi } \\
\text { dan Koperasi }\end{array}$ & $\begin{array}{l}\text { Kegiatan transmigrasi dijalankan berdasarkan } \\
\text { UU. No. } 3 \text { tahun } 1972 \text { dan PP No. } 42 \text { tahun } \\
1973 \text { tentang penyelenggaraan transmigrasi }\end{array}$ \\
\hline Pelita II & $\begin{array}{l}1974 / 1975- \\
1978 / 1979\end{array}$ & $\begin{array}{l}\text { Departemen Tenaga Kerja } \\
\text { Transmigrasi dan } \\
\text { Koperasi }\end{array}$ & $\begin{array}{l}\text { - Rumah sudah dibangun oleh Departemen } \\
\text { Tenagakerja Transmigrasi dan Koperasi di } \\
\text { daerah Transmigrasi } \\
\text { - Program Transmigrasi Bedol Desa }\end{array}$ \\
\hline
\end{tabular}

\footnotetext{
2 Program Pola Sitiung terkenal karena penduduk yang dipindahkan dengan cara bedol (cabut) desa atau satu kampung bersamaan pindah, dan jumlah total desa yang dipindahkan adalah 41 desa yang berasal dari Wonogiri. Pemindahan ini sebagai akibat dari proyek bendungan Gajah Mungkur. Penduduk yang berpindah kurang lebih 2.000 kk dengan jumlah 65.517 jiwa. Penduduk dipindahkan ke 4 desa baru, yaitu Sitiung, Tiumang, Sialanggang, dan Kotosalak di Sawahlunto-Sijunjung Sumatera Barat.
} 


\begin{tabular}{|c|c|c|c|}
\hline Pelita III & $\begin{array}{c}1979 / 1980- \\
1983 / 1984\end{array}$ & Departemen Transmigrasi & $\begin{array}{l}\text { Sama seperti sebelumnya, tetapi orientasi } \\
\text { transmigrasi bergeser dari bidang } \\
\text { kesejahteraan sosial ke sektor ekonomi dan } \\
\text { keuangan }\end{array}$ \\
\hline Pelita IV & $\begin{array}{l}1984 / 1985- \\
1988 / 1989\end{array}$ & $\begin{array}{c}\text { Departemen Transmigrasi } \\
\text { dan Pemukiman } \\
\text { Perambah Hutan (PPH) }\end{array}$ & $\begin{array}{l}\text { - Ditingkatkannya kerjasama dengan } \\
\text { swasta } \\
\text { - Panca Matra Transmigrasi Terpadu } \\
\text { - Pengembangan pola usaha lain selain } \\
\text { tanaman pangan, yaitu hutan tanaman } \\
\text { industri (HTI), perkebunan industri rakyat } \\
\text { (PIR), jasa industri, perikanan dan } \\
\text { peternakan }\end{array}$ \\
\hline Pelita V & $\begin{array}{l}1989 / 1990- \\
1993 / 1994\end{array}$ & Departemen Transmigrasi & $\begin{array}{l}\text { Pengembangan pertanian tetap dilanjutkan } \\
\text { tetapi lebih ditingkatkan pola perkebunan } \\
\text { perikanan dan hutan tanaman industri (HTI). }\end{array}$ \\
\hline Pelita VI & $\begin{array}{l}1994 / 1995- \\
1998 / 1999\end{array}$ & $\begin{array}{c}\text { Departemen Transmigrasi } \\
\text { dan PPH }\end{array}$ & Adanya transmigrasi swakarsa mandiri (TSM) \\
\hline
\end{tabular}

Sumber: Kementerian Desa, Pembangunan Daerah Tertinggal, dan Transmigrasi RI, 2015

Paska Orde Baru, pemerintah menjalankan transmigrasi dengan prinsip kerjasama antardaerah pengirim dan penerima transmigran. Fokus transmigrasi pada masa ini adalah Kota Terpadu Mandiri (KTM). KTM adalah kawasan transmigrasi yang pembangunan dan pengembangannya dirancang menjadi pusat pertumbuhan yang mempunyai fungsi perkotaan melalui pengelolaan sumber daya alam yang berkelanjutan (Kemendesa, 2015:8). Transmigrasi yang dilakukan mulai dari era reformasi sifatnya lebih kepada pendanaan pribadi dan sukarela. Sekalipun demikian, transmigrasi masih diharapkan dapat berjalan dengan baik untuk mendukung pembangunan secara merata. Meskipun program transmigrasi masih eksis di dalam program pemerintah pasca Orde Baru, akan tetapi trend transmigrasi terlihat menurun di bawah pemerintahan Presiden Abdurahman Wahid (Adhiati, M.Adriana Sri; Bobsien, 2001).

\section{- Tanah Papua Sebagai Wilayah Penerima Transmigrasi}

Konsep "Tanah Papua" menjadi identitas penting sejak pendirian Provinsi Papua Barat melalui UU 45 tahun 1999, sebelumnya pulau besar Papua dan pulau-pulau kecilnya hanya ada dalam 1 provinsi, yaitu Provinsi Papua (sebelumnya Irian Jaya). Penyebutan Tanah Papua, merujuk pada dua provinsi yang ada sekarang, yaitu provinsi Papua dan Papua Barat. Penyebutan "tanah Papua" adalah simbol identitas bahwa kedua provinsi tersebut mempunyai aspirasi yang sama agar adanya penghormatan terhadap hak-hak Orang Asli Papua (OAP) mendapatkan perhatian yang serius dari pemerintah.

Walaupun tulisan ini menggunakan konsep "Tanah Papua", tetapi yang menjadi lokusnya adalah Provinsi Papua Barat, khususnya wilayah kabupaten Sorong dan kota Sorong. Lokus kota dan kabupaten Sorong dikarenakan sebagian wilayah kabupaten Sorong menjadi kota (madya) Sorong pada tahun 2000. Konteks lokus ini menjadi 
penting untuk diketengahkan, mengingat pola mobilitas transmigran yang sebelumnya hanya di wilayahan (kabupaten) Sorong, sekarang ada di wilayah kabupaten dan kota Sorong. Peta 1 akan memperlihatkan posisi Sorong dengan wilayah transmigrasi Segun.

Peta 1. Wilayah Kepala Burung, Provinsi Papua Barat

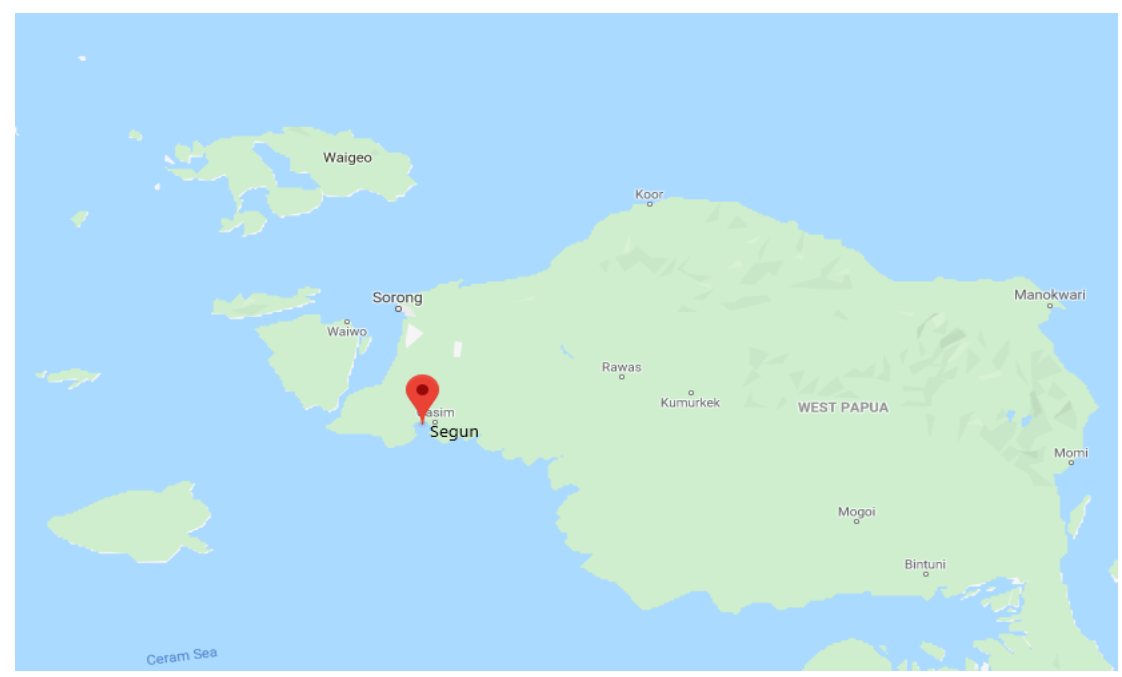

Sumber: googlemaps, 2020

\section{- Segun sebagai Unit Transmigrasi}

Segun dan Sorong terletak di kepala burung pulau Irian yang saat ini menjadi provinsi Papua Barat. Melalui peta dapat terlihat bahwa Segun dan Sorong (sebagai tempat pendaratan pertama penduduk transmigran) masih berada dalam satu daratan. Sayangnya, pada tahun 1997 sampai sekarang akses transportasi darat dari Segun ke Sorong belum tersedia dengan baik. Jarak antara Segun dan Bandara Domine Eduard Osok yang terletak di Kota Sorong adalah $62.42 \mathrm{~km}$. Wilayah bandara ini dulunya juga merupakan lokasi transmigrasi awal pada tahun 1977. Segun saat ini menjadi salah satu distrik di Kabupaten Sorong dengan luas wilayah 2,021.37 km² dan memiliki jumlah 1,765 penduduk pada tahun 2017 (Sorong, 2018). Luas wilayah Segun menempati peringkat kedua setelah distrik Salawati Selatan.

Melalui pengakuan informan diketahui bahwa lahan di Segun sangat baik untuk perkebunan. Hal ini dirasakan betul oleh Karmidi dan Karmila karena jagung, kedelai dan kasbi yang mereka tanam dapat bertumbuh dan berbuah dengan baik. Namun, kondisi tanah yang baik untuk perkebunan ini tidak didukung dengan kondisi infrastruktur yang baik. Karmidi mengungkapkan bahwa sampai sekarang penerangan di Segun menggunakan diesel dan hanya menyala pada sore hari. Kurangnya fasilitas penerangan di Segun adalah hal yang 'biasa' apabila dibandingkan dengan wilayah lain yang ada di Papua Barat, misalnya di Kabupaten Tambrauw. Ditambah lagi kondisi jalan yang sampai saat ini hanya bisa dilalui oleh sepeda motor, sayangnya apabila hujan jalanan tidak bisa dilewati karena licin. Kondisi ini membuat warga susah untuk menjual hasil kebunnya, sekalipun hasil panen melimpah. 


\section{- Kisah Keluarga Karmidi}

Keputusan menjadi transmigran adalah pilihan yang sulit bagi Karmidi muda seorang petani muda dari Salatiga, Jawa Tengah. Ia harus berhadapan dengan dua tantangan sekaligus, yaitu tantangan situasi kemiskinan di kampungnya karena luas lahan yang kecil serta kurang suburnya tanah di kampungnya. Tantangan kedua, kehidupan sebagai bagian dari keluarga Jawa dimana kalau mengadu nasib ke ngetan ngalor dianggap kurang berkenan, yaitu pergi timur-utara bukanlah preferensi bagi orang Jawa, minimal orang Jawa di kampungnya Pada sisi lainnya, Karmidi muda dianggap sebagai anak yang paling diandalkan dan disayangi oleh orangtuanya. Kemudian mengandalkan rujukan dari teman sekampungnya dan juga poster-poster yang menggaambarkan kehidupan di wilayah transmigrasi Irian Jaya sebagai daerah yang gemah ripah loh jinawi, yaitu gambaran tentang kesuburan lahan dan berbagai tanaman pertanian dan tanaman ekonomis lainnya merupakan modal Karmidi muda untuk meyakinkan orangtuanya Apalagi saat itu ia sudah menikah dan mempunyai 2 orang anak. Tekadnya sangat kuat untuk mengubah nasib. Ia menggunakan istilah "transmigran itu bukan orang miskin yang dibuang, tetapi untuk mencari kekayaan dan kemakmuran”.

Perjalanan mengubah nasib itu dimulai pada Sabtu Pon, 22 Agustus 1992 menjadi hari yang paling diingat oleh pasangan Karmidi dan Karmila karena pada hari tersebut mereka mengikuti program transmigrasi yang diinisiasi oleh pemerintah. Mereka bersama kedua anaknya akan pindah dari Salatiga ke Segun di Papua. Sebelum berangkat menuju Segun, mereka harus menginap 10 hari di Semarang. Penerbangan dari Semarang melalui lapangan Kalibanteng (Saat ini dikenal sebagai Bandara Achmad Yani).

Dari Lapangan Kalibanteng, para transmigran dari Semarang turun di Bandara Jefman, Sorong. Pak Karmidi mengingat dengan baik pesawat berangkat pkl 5.30 WIB, tiba di Ambon Pkl 12.00 WITA dan pkl 15.00 WIT sudah tiba di bandara pulau Jefman di Sorong.

Sesampainya di Bandara Jefman, para transmigran kemudian diinapkan selama satu minggu di daerah Remu (sekarang Pasar Sorong). Setelah satu minggu di Sorong, para calon transmigran diberangkatkan menuju Segun. Perjalanan menuju Segun menggunakan kapal ferry yang saat itu menjadi kapal perintis. Mereka berangkat pukul 23.00 dan seharusnya sampai di lokasi pada pukul 8.30, sayangnya ada musibah yang menimpa kapal tersebut. Kapal perintis yang mereka tumpangi diterjang ombak dan semua barang yang dibawa hanyut terbawa ombak. Karmidi mengakui pula kemungkinan kapal mengalami musibah karena muatan yang dibawa terlalu banyak. Sepengetahuannya, kapal seharusnya hanya mengangkut $400 \mathrm{KK}$ transmigran, tetapi menjadi 450 KK dikarenakan untuk memenuhi target penduduk yang dibawa ke Segun. Belum lagi kapal harus membawa muatan bahan-bahan pokok dan juga membawa kapur untuk mengurangi keasaman tanah di wilayah transmigrasi. Musibah tersebut sangat membekas dalam ingatan pak Karmidi. 
“... [T]api ada musibah besar-besaran, kapal perintisnya dibawa ombak. Akhirnya barang-barang yang dibawa kintir semua. Orang-orangnya selamat. ... bahan makanan sudah amburadul. Indomie, roti... seharusnya tiba di Segun Pkl 09.00 pagi, akhirnya baru tiba pkl 18.00" - (Wawancara mendalam, 28 Desember 2019).

Hujan turun sesampainya mereka di Segun, dalam kondisi setelah terkena musibah, hal pertama yang dilakukan oleh Karmidi dan Karmila adalah menggendong anak-anak ke pantai dan berusaha menyelamatkan beberapa barang. Sayangnya, hal tersebut tidak berjalan sesuai dengan rencana. Barang-barang yang mereka tinggalkan sementara di pantai ternyata ketika mereka kembali telah hilang, diantaranya alat-alat perkebunan dan alat masak seperti panci. Karmila menceritakan juga bagaimana suasana begitu menyedihkan saat pertama kali turun di Segun. Ditambah lagi ketakutan mereka yang belum mengenal penduduk lokal di Segun.

“Turun pertama kali ke Segun menderita, karena orang-orang sudah 'nyambut' dengan parang. Jadi nyeri" - (wawancara mendalam, 28 Desember 2019)".

Sesampainya di Segun, para transmigran diinapkan selama 3 hari di balai desa. Kemudian mereka diberikan ijin untuk memilih rumah yang akan mereka tempati di sana, Karmidi dan Karmila menempati wilayah satuan pemukiman (SP) 2 Segun. Kepala Unit Pemukiman Transmigrasi (UPT) memberikan pesan kepada mereka untuk mencari rumah terlebih dahulu, kemudian membersihkan sendiri rumput-rumput yang tumbuh di sekitar rumah sebagai tanda rumah tersebut sudah ditempati. Mereka menceritakan bahwa rumput di sekitar rumah pada saat mereka datang sudah meninggi.

Satu tahun pertama mereka tinggal di Segun, Karmila dan Karmidi mengaku mendapatkan bantuan beras dari pemerintah sebanyak $42 \mathrm{~kg}$. Bahan pokok lain juga diberikan pemerintah untuk bertahan hidup diantaranya ikan asin, minyak goreng, minyak tanah, gula dan sabun. Bantuan ini dikenal sebagai jadup (jatah hidup). Bantuan ini diberikan dengan asumsi maksimal 3 tahun setelah kedatangan transmigran, hasil tanah dari perkebunan baru dapat memberikan hasil optimal. Sayangnya bantuan beras yang diberikan untuk satu tahun pertama dibawa bersamaan dengan kapal perintis yang mereka tumpangi. Alhasil beras yang mereka dapatkan bercampur dengan pasir pantai karena banyak yang hanyut di laut. Bantuan beras dikirimkan pertama kali ke Sorong kemudian didistribusikan ke daerah-daerah transmigran, sayangnya akses jalan yang menyambungkan Sorong dan Segun hancur, mobil pengangkut tidak bisa lewat, serta akan berisiko apabila mengirimkannya melalui laut. Akhirnya para transmigran di Segun mengusahakan tanah di sana untuk menanam tanaman perkebunan seperti jagung, kedelai, dan kasbi.

\section{Ketika Ekonomi Mulai Berjalan}

Sebagai keluarga transmigran, mereka mendapatkan tanah dan pekarangan seluas 2500 $\mathrm{m}^{2}$, ditambah dan tanah untuk pertanian $7500 \mathrm{~m}^{2}$. Langkah pertama yang dilakukan keluarga kecil ini adalah membersihkan alang-alang yang menutupi rumah barunya. Dibutuhkan waktu 10 hari untuk membersihkannya, dan penuh kehati-hatian khawatir ada ular yang ada di persil pekarangan itu. Setelah itu barulah menggarap tanah di pekarangan untuk menanaman beberapa jenis sayuran 
Karmidi dan Karmila mengakui tanah Segun begitu subur, segala jenis bibit yang mereka tanam berhasil. Mereka berdua berbagi tugas untuk merawat dan menjaga kebun karena ada ancaman hama yaitu babi liar yang siap melahap hasil perkebunan. Karmila menceritakan perjuangannya begadang untuk menjaga kebunnya. Sayangnya, akses untuk menjual hasil perkebunan ke Sorong terbatas. Jalan rusak, sehingga tidak bisa dilalui mobil untuk mengangkut hasil dalam jumlah banyak. Akhirnya untuk menjual hasil perkebunan mereka menggunakan perahu johnson menuju Sorong. Bekerja mengolah tanah untuk mendapatkan pendapatan dimulai dari persil seluas 2500 $\mathrm{m}^{2}$ yang ditanami kacang tanah, kedelai, kasbi (ubi) dan kacang panjang. Karena tanaman-tanaman tersebut dapat dijual sekaligus dikonsumsi anggota rumah tangga. Kemudian juga menanam tembakau, agar kalau ingin merokok tidak perlu membeli. Setelah 3-4 bulan, panen pertama sekaligus hasil dari lahan sendiri sudah dapat dijual. Kacang tanah merupakan komoditas yang paling laku dijual dengan harga antara Rp.5000-Rp.800 per kilogram. Pada saat memasarkan hasil pertanian ke Sorong bukan hal yang mudah, transmigran harus menggunakan longboat untuk menuju ke pasar.

\section{Pindah Ke Kota Sorong}

Ketika Jadup dari pengelola transmigrasi tidak diberikan lagi, sementara akses sarana dan prasarana dari Segun ke Sorong masih sulit, tantangan hidup mulai sulit di Segun. Kondisi ini diperparah dengan banyaknya hama yang memakan hasil pertanian milik trasmigran. Pak Karmidi mengingat dengan sangat baik, bahwa pada tahun 1995-1997 adalah waktu dimana hama sangat mengganggu petani. Hama itu adalah kangguru, rusa dan babi hutan. Kanguru dan rusa dagingnya masih dapat dikonsumsi, tetapi babi hutan tidak dimakan dan binatang yang paling rakus. Walaupun para transmigran menjaga di gubuk-gubuk tinggi, tetapi dalam semalam kawanan babi hutan dapat menghabiskan $1 / 4$ ha tanaman jagung.

Pada saat itu, kerawanan pangan dirasakan oleh transmigran di Segun, mereka mencoba memakan kasbi yang direndam, kemudian diperas untuk dapat pati-nya. tetapi rasanya seperti makan pasir. Diakui kalau para orangtua masih bisa bertahan dengan makanan seperti itu, tetapi anak-anak akan sulit untuk memakannya. Lokasi transmigrasi di Segun sangat lambat perkembangan infrastukturnya, bahkan hingga hari ini listrik belum masuk ke lokasi transmigrasi. Padahal Segun sekarang sduah menjadi 2 wilayah kelurahan, tetapi kondisi jalan masih belum terakses dengan baik. Apalagi situasi tahun 1995, infrastruktur yang buruk dan hama yang mengganas membuat transmigran mulai merencanakan mencari tempat baru untuk menyambung hidup.

Untuk memenuhi kebutuhan hidup yang berat di Segun, pada tahun 1996 Karmidi bersama dengan beberapa kepala keluarga transmigran di Segun mencari pekerjaan sebagai kuli di daerah lain. Ia mengaku merantau bekerja sebagai kuli sampai ke daerah Sorong dan Batanta, Kabupaten Raja Ampat sekarang. Karmila yang ditinggal merantau oleh suaminya pun tidak tinggal diam. Ia tetap mengusahakan kebun untuk menutupi kebutuhan sehari-hari. Sesekali juga mereka membeli beras di Segun walaupun harganya jauh lebih mahal dibandingkan makan hasil kebun sendiri. 
Berbekal jejaring pertemanan dan solidaritas di kalangan transmigran Segun, serta hubungan sesama orang Jawa di kota Sorong, Pak Karmidi mendapatkan ajakan untuk menanam sayur (nyayur) di daerah Klasaman. Pada tahun 2000 mereka pindah ke daerah Klasaman, distrik Klaurung, Sorong. Daerah Klasaman ini juga merupakan daerah transmigrasi pemerintah tahun 1977. Karmidi dan Karmila mengusahakan tanah di Klasaman dengan berkebun jagung, melon, dan semangka. Bibit dan obat diakui mereka merupakan bantuan dari kelompok tani penyuluh dari pemerintah. Hal yang menarik pada saat mereka mengusahan tanah di Klasaman, mereka tidak perlu menyewa kepada penduduk lokal, yaitu Orang Moi dari Fam Maribela. Penduduk lokal sebagai pemilik tanah kebun senang kalau tanahnya bisa 'terang' atau dipelihara dengan baik. Sebagai pemakai lahan pun Karmidi dan Karmila juga memberikan sebagian hasil kebun untuk pemilik lahan.

"sayur juga bisa numpang di kilo 15, (sampai sekarang) tanam di Klasaman. Punya orang Maribela, orang Moi. Ya gak ada sewa. Mereka senang kalau tanahnya terang, dipelihara. Asal kalau ditengok kasih sayur ke mereka. Panen jagung kasih jagung." (wawancara mendalam, 28 Desember 2019).

Menurut Pak Karmidi, sejarah persil tanahnya itu dapat dirunut sejak awal, yaitu sebagai tanah adat yang dikuasai oleh orang-orang Suku Moi, sebagai penduduk asli wilayah Sorong. Wilayah tersebut kemudian dibebaskan pemerintah untuk kepentingan transmigrasi pada tahun 1976. Setelah digunakan oleh transmigran, terjadi beberapa kali perpindahan kepemilikan. Setelah menjadi area transmigrasi, tanah tersebut dikuasai oleh Pak Boymin orang Trenggalek, kemudian dibeli oleh orang Jawa pemiliki kios, kemudian pindah tangan lagi kepada orang Jawa lain. Kemudian tanah tersebut dibeli oleh Pak Zainal orang Padang, yang kemudian tanahtanah dijadikan kaveling-kaveling, dimana Pak Karmidi menjadi salah seorang pembelinya dan menetap hinggga kini.

Sekalipun sudah memiliki rumah di Klasaman, tanah dan rumah mereka di Segun tidak mereka jual. Mereka berharap di masa depan, akan ada pembangunan jalan aspal dari Sorong ke Segun. Mereka percaya, pembangunan jalan akan membuka 'perayaan' tanah Segun. Sayangnya, hanya sedikit dari transmigran satu generasi dengan mereka yang masih bertahan di Segun, tepatnya di SP2. Karmidi mengingat hanya tersisa 2 KK di SP2 dari sebelumnya berjumlah $45 \mathrm{KK}$. Beberapa dari keluarga ini memilih untuk kembali ke Jawa ataupun merantau ke tempat lain karena Segun dianggap tidak menguntungkan. Layaknya cerita Karmidi, banyak kepala keluarga yang akhirnya bekerja di luar, seperti di Sorong atau bahkan pulau lain.

Pak Karmidi mengembangkan relasi sosial yang menganggap semua penduduk yang dikenalnya sebagai "saudara saya sesama orang Indonesia". Ia memulai relasi sejak tahun 1992 dengan para calon transmigran yang ditempatkan di Irian Jaya (pada waktu itu). Terdapat $450 \mathrm{KK}$ calon transmigran yang berasal dari Jawa Barat, Jawa Tengah dan jawa Timur dinarasikannya sebagai "saudara sesama Indonesia". Demikian halnya ketika masa awal berinteraksi dengan OAP di sekitar wilayah transmigrasi selalu disebutkan sebagai "saudara saya sesama orang Indonesia". 
Relasi dengan OAP, khususnya dengan orang-orang dari berbagai sub-etnis OAP yang berasal dari Papua dan Papua Barat dijalinnya dengan baik. Pak Karmidi dengan lancar menyebut nama-nama orang-orang Inawatan, Merauke, Fakfak, dan Biak, yang dikenalnya. Ia juga dengan lancar menyebutkan nama-nama fam (marga) dari wilayah Manokwari dan Sorong, serta menyebutkan bahwa orang-orang Moi adalah yang menguasai tanah-tanah di wilayahnya, sebelum dijadikan permukiman transmigrasi. Pak Karmidi mengetahui bahwa wilayah Sorong dikuasai oleh beberapa fam, tetapi untuk wilayahnya adalah orang Moi. Bahkan Pak Karmidi tahu siapa yang dianggap sebagai "kepala suku" di wilayah orang Moi yang menguasai wilayah adat disitu. Bagi Karmidi, OAP dari berbagai wilayah Papua ini "saya jadikan saudara!". Cara pandang Karmidi inilah yang menyebabkan perbincangan pada bulan Agustus 2019 tidak terasa ada pandangan negatif terhadap adanya narasi pertentangan antara OAP dengan migran seperti Pak Karmidi. Demikian halnya pak Karmidi tidak menginginkan perbincangan yang mengarah pada situasi yang sedang terjadi di pusat kota Sorong.

Pandangan yang agak berbeda dimiliki oleh menantu Pak Karmidi yang berlatar belakang etnis Bugis. Ia merasa ada relasi yang tidak nyaman antara OAP dengan para pendatang, khususnya orang Bugis dan Jawa. Menantunya ini memberikan informasi bahwa saat itu orang-orang Jawa di Sorong terancam, sasaran-sasaran perusakan adalah toko atau tempat usaha oranh-orang Jawa. Alasannya karena peristiwa rasisme terjadi di wilayah Jawa Timur, sehingga orang Jawa menjadi sasaran.

Keluarga Karmidi dan Karmila merupakan salah satu contoh transmigran yang berhasil beradaptasi bahkan mengalami perubahan status di daerah transmigrasi. Awalnya pasangan suami istri ini mengaku bahwa mereka berniat untuk berpindah dari Salatiga menuju Segun karena tidak memiliki kehidupan yang layak di daerah asal. Mereka mengaku tidak memiliki rumah di Salatiga dan sangat ingin agar anak-anaknya dapat hidup layak di masa depan. Terbukti saat ini mereka berhasil memiliki lahan dan rumah yang layak di Sorong dan Segun. Rumah di Segun belum mereka jual karena mereka percaya bahwa ke depannya pemerintah akan mengaspal jalan dari Sorong menuju Segun.

Apa yang dilakukan oleh keluarga Karmidi mungkin dapat memenuhi anggapan umum bahwa pendatang memiliki keinginan yang lebih kuat untuk berhasil dibandingkan penduduk lokal. Tekad dan motivasi Karmidi untuk hidup yang lebih baik di Segun bukan hanya dipengaruhi oleh keadaan di tempat yang mereka baru tempati, tetapi juga dipengaruhi oleh keadaan di daerah asal yang menyebabkan mereka tidak bisa kembali begitu saja. Kasus Karmidi masih sesuai dengan teori klasik migrasi dari Everett Lee (Lee, 1966, p. 50) yaitu adanya faktor penarik dan pendorong bagi orang melakukan perpindahan. Keadaan yang tidak menguntungkan secara ekonomi menjadi faktor pendorong bagi keluarga ini untuk berpindah, disamping itu adanya lapangan pekerjaan dan tersedianya pemukiman menjadi faktor pendorong mereka untuk berpindah.

Keluarga ini bisa beradaptasi dengan baik tentunya tidak lepas dari cara mereka mengoptimalkan sumber daya manusia yang dimiliki di dalam keluarga. Karmila sebagai istri mengambil peran yang sama sebagai pengelola kebun bersama dengan 
suaminya. Bahkan ketika sang suami harus pergi menjadi kuli di tempat lain, Karmila mengambil peran sebagai pengolah kebun demi menghidupi kedua anaknya. Perempuan mengambil peran dalam pengelolaan kebun juga ditemukan dalam studi kasus Winarto dan Utami (2012) pada kelompok tani Menur di Gunung Kidul, Yogyakarta. Mereka menyatakan bahwa bangkitnya kelompok tani perempuan bermula dari kenaikan jumlah migrasi dari laki-laki di desa, oleh karena itu perempuan harus mengambil alih beberapa pekerjaan termasuk mengelola lahan dan hewan ternak (Winarto \& Utami, 2012, p. 277).

Kembali kepada Karmidi dan Karmila, mereka berdua juga berhasil menjalin kerjasama dengan penduduk lokal yang memiliki tanah sehingga konflik dapat dihindari. Hal ini terlihat dari bagaimana mereka membagi hasil kebun kepada pemilik tanah sebagai ganti uang sewa yang memang tidak diminta oleh penduduk lokal.

Adaptasi yang berhasil dilakukan oleh keluarga Karmidi membuat mereka berhasil memiliki rumah dan tanah di Klasaman. Terjadi perubahan dari yang tidak memiliki rumah sendiri di Salatiga kemudian berhasil memiliki rumah di Klasaman dan Klasegun. Awalnya keadaan susah harus mereka hadapi baik secara geografis maupun sosial. Perbedaan tersedianya fasilitas antara Jawa dan Papua, terutama dalam hal akses jalan aspal sempat menjadi masalah bagi para transmigran di Segun. Ditambah lagi mereka harus bekerja keras untuk mengusahakan lahan untuk perkebunan. Namun, masalah ini terbukti menguji ketahanan dari keluarga Karmidi dan bekerja lebih keras sebagai transmigran.

Riwayat perjalanan keluarga Karmidi memperlihakan bahwa sebuah keluarga transmigran dapat bertahan karena kemampuannya untuk (1) menerabas tantangan budaya dari daerah pengiriman. Hal ini dapat dlihat dari cara pak Karmidi untuk meyakinkan keluarga dan kerabatnya bahwa daerah "ngalor ngetan" yang dianggap sebagai tempat yang kurang baik untuk didatangi adalah daerah yang "subur makmur ijo royo-royo" dengan cara memeperlihat poster-poster dari kementerian transmigrasi (2) melawan tantangan kesulitan lingkungan wilayah transmigrasi, dengan cara tetap bertani untuk komoditas yang mempunyai pasar yang bagus di Sorong, yaitu Jagung, kacang tanah dan kedelai (3) mencari tempat tinggal yang baru dengan basis pertanian, tetapi tidak menjual aset di wilayah transmigrasi, sehingga keluarga ini mempunyai asset untuk bertahan hidup sekaligus untuk diwariskan kepada anak-anaknya dan (4) strategi jejaring dengan OAP dan migran lainnya, yaitu dengan mengembangkan sikap plural terhadap OAP yang selalu dianggap "saudaraku se-Indonesia", maupun dengan migran Jawa lainnya dan migran dari daerah lainnya di Indonesia. Pak Karmidi tidak tertarik membahas tentang situasi menegang antara OAP dengan etnis Jawa, tetapi lebih mengedepankan cerita-cerita kedekatan dengan OAP dari berbagai sub-etnis. Selain itu, Pak Karmidi juga menggunakan arena mushala yang ia bangun sebagai tempat untuk memperkuat relasi ketetanggaan di tempatnya sekarang.

\section{- Kisah Keluarga Pak Guru Joko}

Keluarga transmigram lain yang kami temui di Sorong adalah keluarga Pak Joko. Berbeda dengan Pak Karmidi, Pak Joko sekarang tinggal di Kabupaten Sorong di wilayah yang berbatasan dengan Kabupaten Tambrauw. Pak Joko saat ini adalah 
pegawai dispenda Kabupaten Tambrauw. Perjalanan Pak Joko cukup menarik karena pernah mengabdikan diri sebagai guru di pedalaman Papua sebelum akhirnya menjadi pegawai negeri Kabupaten Tambrauw.

Pada tahun 1980, orangtua Pak Joko memutuskan untuk mengikuti program transmigrasi ke Papua. Saat itu Pak Joko masih duduk di sekolah dasar dan tidak ikut menentukan keputusan mereka ke Sorong, Papua. Berasal dari Pulau Jawa, tepatnya Nganjuk, Papua menjadi tempat yang sangat berbeda dari tanah kelahirannya. Ia menceritakan saat awal pindah ke Sorong belum ada sekolah menengah pertama (SMP) yang dekat dengan rumahnya sebagai transmigran. Akhirnya Ia harus berjalan kaki sangat jauh karena transportasi umum belum ada juga saat itu. Sebagai anak yang mengikuti orangtua sebagai transmigran Ia mengikuti saja keputusan orangtuanya walaupun hidup sangat berbeda dengan yang Ia jalani sebelumnya di Nganjuk.

Pak Joko saat itu tidak memiliki keinginan khusus ingin berprofesi sebagai apa kelak saat dewasa. Ia memilih sekolah pendidikan guru (SPG) di Sorong yang saat itu dikelola oleh yayasan keagamaan Katholik. Di tempat tersebut Ia belajar bagaimana menjadi guru yang baik dan hatinya pun perlahan mencintai Sorong. Ia ingin agar pendidikan juga bisa dirasakan oleh semua anak Papua. Setelah menamatkan sekolah pendidikan guru, Ia kemudian ditugaskan untuk mengajar ke daerah pedalaman di Aifat. Ia bercerita saat itu hanya diberikan alamat desa yang dituju. Perjalanan menempuh waktu beberapa hari dan masuk ke dalam hutan. Ia sempat kelelahan di tengah hutan dan terpikir untuk kembali ke Sorong. Akan tetapi kemudian Ia teringat apa yang Ia pelajari di sekolah dan bertekad untuk melanjutkan perjalanan untuk mengajar anak-anak di Aifat.

"Saya sempat mau kembali lagi, benar itu. Tapi kemudian ada hati bilang, kalau bukan saya yang datang, siapa lagi yang mau datang dan mengajar anak-anak itu. Akhirnya saya lanjutkan perjalanan meskipun rasanya sedih sekali."

Sesampainya di Aifat ternyata benar belum ada guru yang masuk ke sana. Hal yang menjadi menarik dari cerita Pak Joko saat itu Ia disambut dengan hangat. Penduduk di Aifat sudah menyiapkan sebuah pondok baginya untuk tinggal selama di Aifat. Walaupun dalam kondisi seadanya akan tetapi semua orang berusaha betul memenuhi kebutuhannya sebagai seorang guru di sana. Ia mengaku dirinya sangat tersentuh dengan penerimaan orang-orang di sana. Pak Joko mengajar di Aifat sementara selama enam bulan karena saat itu anaknya baru lahir dan belum bisa diajak untuk menetap di Aifat. Setelah enam bulan, Ia kembali ke rumah dan mengajak istri dan anaknya yang saat itu berumur setahun untuk menetap di Aifat. Di sana kebutuhan mereka didukung oleh hasil kebun penduduk Aifat. Ia mengatakan bahwa semua orang di Aifat menghargai kehadiran seorang guru dan menurutnya anak-anak yang dulu Ia ajar di Aifat saat ini menjadi orang-orang berhasil.

"Orang di Aifat itu hormat betul sama guru. Mereka ndak mau kalau gurunya pergi. Orangtua, anak semua menghormati guru. Saya senang mengajar mereka. Bisa dicek, anak-anak yang dulu saya ajar sekarang jadi orang semua."

Pak Joko tidak selamanya menetap di Aifat, Ia beberapa kali dipindahkan di wilayah Papua untuk mengajar dan memimpin sekolah. Ia pernah menjadi kepala sekolah di 
Makbon dan tahun 2010 ditugaskan di Tambrauw untuk menjadi Kepala Dinas Pendidikan. Hingga akhirnya saat ini Ia tercatat sebagai pegawai dispenda Kabupaten Tambrauw dan menetap di Kabupaten Sorong. Ia mengatakan bahwa Ia percaya dan menaruh harapan terhadap Papua, khususnya Tambrauw yang saat ini merupakan kabupaten baru. Ia percaya pembangunan akan bisa merata di Papua asalkan semua memiliki hati untuk membangun Papua. Ia mengatakan pada dasarnya orang Papua mau belajar akan tetapi aksesnya harus dibuka supaya mereka bisa menerima semua fasilitas yang diberikan pemerintah. Ia percaya suatu saat Papua bisa maju seperti di Jawa asalkan jangan menutup mata terhadap semua kekurangan yang ada dan kemudian berusaha membangun lebih baik. Saat ini Ia mengaku akan tetap berada di Sorong dan anak-anaknya juga belum ada keinginan untuk pergi menetap keluar dari Sorong.

\section{- Kemiskinan, Ketidaksetaraan, Peran Relasi, Peran Pemerintah dan Gender}

Migrasi berkaitan dengan kemiskinan, peran relasi, peran pemerintah dan gender (Black, Richard; Biao, Xiang; Collyer, Michael; Heering, Godfried Liesbeth Engbersen; Markova, 2006). Kelima aspek tersebut secara umum membentuk pola dan menjadi alasan pendukung dalam melakukan migrasi. Seberapa miskin dan kemungkinan untuk keluar dari kemiskinan dapat disediakan oleh suatu daerah akan mendukung seseorang untuk berpindah. Ketidaksetaraan, misalnya dalam hal kemampuan dalam mengakses fasilitas umum dapat menjadi alasan untuk berpindah ke daerah lain yang dianggap lebih baik.

Kemudian, peran relasi dan pemerintah juga memegang kunci penting dalam terjadi migrasi, misalnya seseorang tertarik berpindah ke daerah lain karena ingin mengikuti kesuksesan saudara atau kerabatnya. Pola migrasi ini seringkali disebut sebagai chain migration ketika perpindahan penduduk akhirnya membentuk suatu kluster penduduk yang berasal dari latar belakang yang sama dan menyediakan kesempatan kerja di daerah tujuan serta memiliki sifat berkelanjutan (Papastergiadis, 2000, p. 29). Kusworo (Kusworo, 2014, p. 25) menarasikan bagaimana transmigrasi mandiri orang Jawa dan Sunda di Lampung yang tidak didanai pemerintah malah mencatatkan jumlah yang lebih besar dikarenakan para migran mengikuti saudara dan kerabatnya yang sudah berhasil karena program transmigrasi sebelumnya. Sekalipun migrasi atas inisiatif sendiri di Lampung lebih tinggi jumlahnya dari program transmigrasi pemerintah, akan tetapi kesuksesan penduduk di Lampung tidak lepas dari campur tangan kebijakan pemerintah. Terakhir, gender juga memberikan pengaruh dalam migrasi, misalnya migrasi hanya dilakukan oleh suami sebagai pencari nafkah sebaliknya istri tetap di daerah asal. Kelima hal ini saling berkaitan dalam menentukan keputusan dan pola migrasi.

Dalam kasus transmigrasi keluarga Karmidi dan Joko keputusan bermigrasi ditentukan oleh 3 faktor penting yaitu kemiskinan, ketidaksetaraan dan peran pemerintah. Kemiskinan dan ketidaksetaraan menjadi alasan keluarganya berpindah dari Salatiga ke Segun. Karmidi sebagai kepala keluarga, dan orangtua Joko menganggap mereka akan mendapatkan kesempatan yang lebih baik dengan berpindah ke luar Jawa. Sulitnya memiliki rumah dan mendapatkan pekerjaan layak di Jawa menjadi faktor pendorong 
keluarganya untuk pindah. Ditambah lagi dengan tersedianya rumah dan lahan di Segun menjadi faktor penarik untuk mendukung keputusannya bermigrasi. Tentu saja peran pemerintah menjadi signifikan bagi keputusan keluarga ini bermigrasi, tersedianya lahan untuk pemukiman dan perkebunan menjadi alasan kuat bagi mereka.

\section{- [Trans]migrasi dan Refleksi Kependudukan Nasional}

Pada dasarnya transmigrasi tidak bisa dilepaskan dari perkembangan teori migrasi dalam perspektif tenaga kerja. Perpindahan penduduk muncul sebagai akibat adanya tekanan untuk mencari sumber pendapatan yang lebih baik di luar daerah asalnya (Massey et al., 1993). Perbedaan geografis seringkali menjadi penyebab utama perbedaan ketersediaan lapangan kerja di daerah asal dengan daerah tujuan. Oleh karena itu perpindahan dilakukan oleh seorang individu atau kelompok demi kehidupan yang lebih baik, hal ini dianggap sebagai pilihan yang rasional. Lebih lagi, migrasi semakin sering dilihat sebagai sebuah 'livelihood strategy' dari orang miskin, sekalipun hanya sedikit bukti yang dapat menyatakan keterkaitan pembangunan ekonomi, pengurangan kemiskinan, pertumbuhan penduduk, dan perubahan sosial politik (Van Hear \& Nyberg-Sørensen, 2002, p. 40). Demikian halnya dengan kebijakan transmigrasi di Indonesia muncul karena perpindahan dianggap sebagai jalan keluar untuk mendapatkan pekerjaan yang lebih baik dan keluar dari kemiskinan.

Di sisi lain, sekalipun migrasi dianggap sebagai jawaban atas masalah kemiskinan, akan tetapi kebijakan migrasi malah mengundang kritik di dalam masyarakat. Setidaknya ada 4 kritik besar terhadap kebijakan migrasi secara umum yaitu tidak efisien, mahal, tidak masuk akal dan menjadi problema etis (Düvell, 2007, p. 48). Kritik ini berdasarkan pada kebijakan migrasi yang seringkali malah mengeksklusi masyarakat dalam perumusannya. Kebijakan migrasi seringkali tidak tepat sasaran dan tidak menyentuh kebutuhan masyarakat, ditambah lagi migrasi yang didukung oleh suatu negara dilaksanakan menggunakan dana yang banyak tetapi tidak sesuai dengan kebutuhan. Di beberapa tempat bahkan kebijakan migrasi yang tidak tepat sasaran ini akhirnya malah memicu konflik di dalam masyarakat.

Di Indonesia, kebijakan migrasi yang didukung pemerintah adalah transmigrasi dan kebijakan ini sudah dilakukan sejak lama dan ada baiknya untuk melihat kembali kebijakan transmigrasi ini apakah sesuai dengan tujuan pembangunan. Pasalnya transmigrasi yang telah dilakukan selama ini belum terbukti dapat mendukung pembangunan nasional. Ditambah lagi, beberapa kejadian transmigrasi justru menjadi awal relasi yang tidak baik diantara penduduk lokal dan pendatang. Hal ini diantara lain tercipta karena adanya stereotipe dan reaksi hubungan situasional-kontekstual yang terjadi di wilayah transmigran.

Transmigrasi telah berhasil membentuk persepsi bagi masyarakat yang wilayahnya dijadikan sebagai tempat tujuan, salah satunya adalah Irian Jaya pada masa Orde Baru³. Penduduk lokal dihadapkan dengan kebudayaan baru yang berbeda dengan dirinya sendiri. Herman Renwarin, Josz Mansoben, dan Daan Dimara (Renwarin, Mansoben, \&

\footnotetext{
3 Irian Jaya merupakan nama yang dipakai sebelum menjadi Papua
} 
Dimara, 1994, pp. 52-54) mencoba membagi sikap antara penduduk asli4 Irian Jaya secara umum terhadap pendatang yang kebanyakan berasal dari program transmigrasi. Sikap dari penduduk asli terhadap pendatang terbagi menjadi tiga bagian besar yaitu sikap terhadap alam semesta, lingkungan sesama, dan dunia baka. Penggambaran sikap penduduk asli selalu bertentangan dengan pendatang, misalnya saja dalam hal menghadapi kegagalan, penduduk asli cenderung konsekuen dan mempersalahkan dirinya sendiri tanpa merasa rendah diri. Sebaliknya pendatang cenderung mempersalahkan situasi yang berada di luar pengawasannya atau kelalaian orang lain yang tidak menolongnya. Gambaran sikap ini memberikan suatu pola pertentangan antara orang asli dan pendatang yang sifatnya masih dipertanyakan apakah kemudian dapat berguna bagi pembangunan.

Dari sifat yang bertentangan kemudian berkembang hubungan reaksional di wilayah baru tempat perpindahan. Beberapa tulisan telah merangkum dengan baik pola hubungan penduduk lokal terhadap pendatang, baik dalam bentuk kompetisi maupun kerjasama. Namun, hubungan diantara penduduk lokal dan pendatang bukanlah suatu hal yang hitam-putih. Hubungan yang terbentuk seringkali bersifat situasional, temporal, dan tergantung dari generasi tertentu. Gerry van Klinken (Klinken, 2007) berhasil menarasikan bagaimana interaksi antara penduduk lokal dan pendatang di Sampit yang berujung konflik. Kemudian Herry Jogaswara (Jogaswara, 2012) dapat menjelaskan rekonsiliasi yang ditempuh oleh warga Sampit pasca konflik. Dalam literatur lain, hubungan kerjasama dapat terbentuk diantara penduduk lokal dan pendatang, diantara Orang Abun dan Orang Biak, seperti yang terjadi di Pulau Dua, Papua Barat (Oktafiani \& Jogaswara, 2019).

Relasi situasional dan kontekstual inilah yang perlu menjadi pertimbangan bagi pemerintah sejauh mana mereka dapat ikut campur tangan dalam upaya persebaran penduduk, karena, bagaimanapun, pemerintah pastinya mengupayakan suatu daerah agar dapat terhindar dari konflik dan dapat mendapatkan keuntungan dari program yang direncanakan. Sebagai contoh, transmigran yang bersedia pindah dibuatkan rumah di daerah tujuan oleh Departemen Transmigrasi dimulai pada masa Pelita II di masa Orde Baru. Dibuatnya pemukiman baru berimplikasi kepada kepemilikan tanah ulayat yang perlu dipikirkan dengan seksama, apakah pembukaan lahan tersebut mensejahterakan penduduk lokal atau malah mengabaikan hak-hak mereka. Apabila hal ini diabaikan bukan tidak mungkin konflik akan terulang dikarenakan situasi yang tercipta malah merugikan penduduk lokal.

Dilihat dalam skala nasional, transmigrasi semenjak masa kolonial sampai era reformasi dilakukan sebagai jalan keluar dari kemiskinan. Kehidupan yang dialami di daerah asal menjadi faktor penentu seseorang untuk berpindah, sementara dalam konteks transmigrasi, daerah tujuan sudah dipenuhi dengan fasilitas kehidupan yang layak. Daerah-daerah di luar Pulau Jawa ditargetkan sebagai daerah tujuan transmigrasi diantaranya, Lampung, Sulawesi Barat, Kalimantan Timur, dan Papua. Dilihat melalui lokasi, para calon transmigran yang bersedia dipindahkan tidak perlu khawatir karena

\footnotetext{
4 Term penduduk asli digunakan sesuai dengan tulisan yang dikutip. Dalam hal ini penulis lebih memilih
} term penduduk lokal untuk menggambarkan posisi masyarakat yang lebih dahulu menetap di suatu daerah 
di daerah tersebut sudah disediakan pemukiman dan lahan untuk bercocok tanam. Ditambah lagi ada bantuan bagi para transmigran selama dua tahun pertama sebelum hasil mereka bercocok tanam dapat memberikan hasilnya. Sayangnya, sekali lagi, karena peraturan yang sifatnya top-down tersebut tidak mempertimbangkan aspek non pangan, sandang, dan papan, seringkali wilayah transmigrasi tidak bisa berkembang dan cenderung terabaikan.

\section{Kesimpulan}

Permasalahan kependudukan di Indonesia telah melalui perjalanan panjang. Bongkarpasang program dengan beragam jenis modifikasi dilakukan untuk mendapatkan hasil yang diinginkan oleh pemerintah atas nama pembangunan, dan dalam tulisan ini mengenai persebaran penduduk. Penyebaran penduduk melalui transmigrasi dipilih dan diyakini sebagai hal yang efektif mengatasi permasalahan kepadatan penduduk di Pulau Jawa sejak masa kolonial dan bahkan masih eksis sampai sekarang. Sayangnya, transmigrasi yang dilakukan pemerintah terbukti menunjukkan kegagalan karena dianggap malah menimbulkan masalah baru, seperti halnya konflik kepemilikan lahan.

Sekalipun dalam skala nasional dianggap gagal tetapi program transmigrasi dapat menjadi jalan keluar bagi sebagian penduduk yang mengikutinya, salah satunya adalah keluarga Pak Karmidi di Segun. Memutuskan untuk menjadi transmigran menjadi jawaban akibat ketidakberdayaan mereka di tanah Jawa. Meskipun jalan yang ditempuh tidak seindah yang dibayangkan akan tetapi keluarga Karmidi berhasil membuktikan bahwa mereka berhasil mengembangkan dirinya di Segun. Hal menarik lain yang bisa dilihat dari keluarga Karmidi adalah bagaimana migrasi permanen kemudian juga membuahkan migrasi sosial bagi mereka. Pasangan Karmidi dan Karmila berhasil memiliki rumah dan lahan untuk diolah bahkan untuk diwariskan kepada keturunannya kelak.

Cerita kedua adalah Pak Joko, seorang yang menghabiskan masa muda di Sorong karena mengikuti orangtuanya menjadi transmigran kemudian malah mengabdikan dirinya menjadi tenaga pendidik di sana. Pak Joko dan keluarga menganggap mereka menjadi bagian dari perkembangan Tambrauw dan Sorong dan ingin agar kualitas pendidikan yang sempat Ia rasakan di Jawa juga bisa dirasakan oleh anak-anak di Papua. Sekalipun tidak bisa memilih untuk menetap di Jawa saat itu, keluarga Pak Joko memilih untuk tinggal di Sorong dan mengabdi di sana. Hatinya melekat bukan di tanah kelahirannya, tetapi di Tambrauw dan Sorong sebagai daerah transmigran. Ia menanti dan percaya bahwa pembangunan akan menyentuh Papua dan apa yang dia pernah rasakan dan tahu terjadi di Jawa akan bisa terjadi juga di Papua, khususnya Tambrauw dan Sorong.

Di sisi lain, transmigrasi juga memiliki potensi masalah bagi daerah yang tidak dipersiapkan dengan baik. Ada potensi kegagalan bagi para transmigran dari sisi ekonomi bahkan kemungkinan akan berlanjut kepada potensi konflik apabila relasi pendatang dan lokal tidak dibenahi dengan baik. Meskipun demikian, strategi adaptasi yang dilakukan keluarga Karmidi dan Joko menjadi menarik karena keberadaan mereka bisa diterima dengan baik oleh penduduk lokal dan bahkan membentuk kerjasama. Hal ini dapat menjadi refleksi pemerintah bagaimana penyiapan mental transmigran untuk 
tidak menyerah di daerah baru menjadi penting daripada sekadar penyiapan pemukiman dan lahan perkebunan. Apabila hal ini menjadi fokus dari pemerintah, bukan tidak mungkin transmigrasi yang dalam skala nasional dianggap gagal dapat bertransformasi menjadi jawaban bagi pembangunan.

\section{Conflict of Interest}

Penulis menyatakan tidak ada konflik kepentingan.

\section{Acknowledgment}

Irin Oktafiani dan Herry Yogaswara berkontribusi pada perancangan dan implementasi penelitian, analisis hasil dan penulisan naskah sebagai penulis utama.

\section{Daftar pustaka}

Adhiati, M.Adriana Sri; Bobsien, A. (2001). Indonesia's Transmigration Programme - An Update. Retrieved June 30, 2020, from https://www.downtoearthindonesia.org/old-site/ctrans.htm

Apomfires, F. (2000). Dimensi Konflik dalam Program Transmigrsi dan Strategi Pemecahannya. In Prosiding Simposium Internasional Jurnal Antropologi Indonesia. Jakarta.

Arndt, H. W. (1983). Transmigration: Achievements, Problems, Prospects. Bulletin of Indonesian Economic Studies Transmigration, 19(3), 50-73. https:// doi.org/10.1080/00074918312331334429

Black, Richard; Biao, Xiang; Collyer, Michael; Heering, Godfried Liesbeth Engbersen; Markova, E. (2006). Migration and Development: Causes and Consequences. In K. Penninx, Rinus; Berger, Maria; Kraal (Ed.), The Dynamics of International Migration and Settlement in Europe (pp. 41-63). Amsterdam: Amsterdam University Press.

Düvell, F. (2007). Towards sustainable migration policies. In J. Michael (Ed.), Innovative Concepts for Alternative Migration Policies: Ten Innovative Approaches to the Challenges of Migration in the 21st Century (pp. 47-58). Amsterdam: Amsterdam University Press.

Harmadi, S. H. B., \& Antarwati, E. (2014). Identifikasi Potensi Transmigran Berdasarkan Karakteristik Migran Di Indonesia. Jurnal Ketransmigrasian, 31(2), 1=16.

Jogaswara, H. (2012). MENERUSKAN HIDUP SETELAH KERUSUHAN: Ingatan Kolektif dan Identitas Etnis Madura Pasca Kekerasan Antar Etnis di Kota Sampit, Kalimantan Tengah. Universitas Indonesia.

Kementerian Desa Pembangunan Daerah Tertinggal dan Transmigrasi RI. (2015). Transmigrasi Masa Doeloe, Kini, dan Harapan Kedepan. Jakarta: Direktorat Jenderal Penyiapan Kawasan dan Pembangunan Permukiman Transmigrasi, Direktorat Bina Potensi Kawasan Transmigrasi.

Klinken, G. Van. (2007). Communal violence democratization in Indonesia: small town wars. New York: Routledge.

Kusworo, A. (2014). Lampung in the Twentieth Century: The Making of 'Little Java.' Canberra: ANU Press.

Lee, E. S. (1966). A Theory of Migration. Demography, 47-57.

Massey, D. S., Arango, J., Hugo, G., Kouaouci, A., Pellegrinoand, A., \& Taylor, J. E. (1993). Theories of International Migration: A Review and Appraisal. Population and Development Review, 19(3), 431-466.

Oktafiani, I., \& Jogaswara, H. (2019). Migrasi Orang Biak dan Identitas Orang Asli Papua 
di Sausapor, Papua Barat. Antropologi Indonesia, 40(1), 1-18.

Papastergiadis, N. (2000). The turbulence of migration : globalization, deterritorialization and hybridity. Cambridge: Polity Press.

Renwarin, H., Mansoben, J., \& Dimara, D. (1994). Persepsi Masyarakat Irian Jaya terhadap Usaha-Usaha Pembangunan. In E. K. . Masinambow \& P. Haenen (Eds.), Kebudayaan dan Pembangunan di Irian Jaya. Jakarta: LIPI-RUL.

Ricklefs, C. M. (2008). A History of Modern Indonesia. New York: Palgrave Macmillan.

Sorong, B. P. S. K. (2018). Kabupaten Sorong Dalam Angka. (B. K. Sorong, Ed.). Sorong: BPS Kabupaten Sorong.

Tirtosudarmo, R. (2013). From Colonization to Nation-state: The Political Demography in Indonesia. Jakarta: LIPI Press.

Van Hear, N., \& Nyberg-Sørensen, N. (2002). The Migration-Development Nexus: Evidence and Policy Option. Geneva: International Organisation for Migration.

Winarto, Y. T., \& Utami, S. P. B. (2012). Women's Empowerment in Persisting and Changing "Family" Norms in Java. In Y. Hayami, J. Koizumi, C. Songsamphan, \& R. Tosakul (Eds.), The Family In Flux in Southeast Asia: Institution, Ideology, Practice (pp. 275-294). Kyoto: Kyoto University Press and Silkworm Books. 